\title{
THE EFFECT OF GOVERNMENT DECISIONS ON THE EFFICIENCY OF THE INVESTMENT FUNDS MARKET IN POLAND
}

\author{
Dorota WITKOWSKA (D) ${ }^{1}$, Krzysztof KOMPA (D) 2*, \\ Grzegorz MENTEL (D)3 \\ ${ }^{1}$ Department of Finance and Strategic Management, \\ Faculty of Management, \\ University of Lodz, Lodz, Poland \\ ${ }^{2}$ Department of Econometrics and Statistics, \\ Faculty of Applied Informatics and Mathematics, \\ Warsaw University of Life Science, Warsaw, Poland \\ ${ }^{3}$ Department of Quantitative Methods, Faculty of Management, \\ Rzeszow University of Technology, Rzeszow, Poland
}

Received 11 November 2018; accepted 11 March 2019

\begin{abstract}
Polish government introduced crucial changes concerning conditions of the pension funds functioning in the years 2011-2014. This article focuses on explaining the impact of these political decisions on efficiency of investment fund market in Poland. Therefore, the article aims (1) to find out if changing in functioning of pension funds also affected the efficiency of mutual funds which provide stable growth investment policy (i.e. similar investment strategy as pension funds) and (2) to check which type of investment funds, pension or mutual, were more efficient in the sense of returns and risks under new regulations. The analysis is provided for selected mutual funds using daily, weekly and monthly returns. The whole period of analysis, years 2009-2015, is divided into six sub-periods according to the three events, that essentially changed the functioning of the pension funds. Statistical tests for in pairs comparisons of returns and risks, and ratios for investment efficiency evaluation were applied. Findings show that pension funds performed better than mutual funds which are managed by the same company. More, the changes of the rules for pension funds' functioning caused an increase of risk and a decrease of efficiency of the considered investment funds' portfolios.
\end{abstract}

Keywords: stable growth open investment funds, OFE, investment performance, CAPM, Sharpe, Treynor and Jensen efficiency ratios.

JEL Classification: G12, G14, G23, G28, E44, D53, C12.

*Corresponding author. E-mail: krzysztof.kompa@gmail.com 


\section{Introduction}

After the transformation of the economic and political system in Poland in the late 1980s, other spheres of the Polish economy and public finances were reformed in the 1990s. One of the most profound reforms concerned the pension system, and it consisted in:

- the replacement of the defined benefit scheme with a defined contribution one,

- introducing the mandatory capital-funded pillar and voluntary fully-funded plans.

The pension system which was introduced in Poland in 1999 seemed to be quite well prepared. However, not all assumptions of the retirement reform were fulfilled by the government, and there also remained some questions which had not been solved ${ }^{1}$. Private financial institutions - pension investment funds ${ }^{2}$ (OFE) - started to operate in 1999 as the mandatory capital-funded pillar, with the number of members increasing from 7 million in 1999 to 16.6 million in 2014. Until 2014, OFEs invested their growing assets mostly in financial instruments issued and traded in Poland, and they became the most important institutional investors on the Polish financial market.

The reform of the retirement system was accompanied by a debate conducted by researchers and politicians, who paid some attention to the private pension funds operating in Poland only at the turn of the century. The discussions about these financial institutions appeared only during the financial crises, when slower GDP growth caused an increase in the public deficit and the public debenture in relation to GDP. As a result, Poland was no longer in line with the Maastricht criteria. Then the pension investment funds became the subject of massive criticism from the government. OFEs were accused of (i) creating the high budget deficit caused by the Social Insurance Fund (FUS), which is a state fund whose financial resources are administrated by Social Insurance Institution (ZUS), (ii) having high activity costs, (iii) low investment efficiency.

As a result of this criticism, the Polish government passed three important regulations concerning the function of pension funds, which first came into effect in 2011 and then in February and August 2014. In 2011, the retirement contribution to the pension funds was reduced from $7.3 \%$ to $2.3 \%$. In February 2014, the most drastic regulation, which consisted in shifting all debt securities issued and guaranteed by the State Treasury, went into effect. In the situation of increasing the budget deficit and government debt ${ }^{3}$, the transfer of $51.5 \%$ of the pension fund assets (about 150 billion PLN) to FUS essentially allowed the Polish government to reduce the government debt and keep it at a level of $51 \%$ of GDP. The overhaul of the pension system also concerned changes in the OFEs' investment portfolio since private pension funds were no longer allowed to invest in government bonds. Some months later, in August 2014, the character of pension funds changed, and they were no longer obligatory due to another significant modification introduced by the Polish government. Thus, since

\footnotetext{
${ }^{1}$ For instance, the decision what institution will pay the retirement benefits from the contribution collected by pension funds was made only in 2008, and the Social Insurance Institution (ZUS) was appointed.

2 Pension funds operate in similar way as mutual funds and create mandatory or voluntary pillars of the pension system in many countries, see (Blake, Wright, \& Zhang, 2014; Brinkman, Coen-Pirani, \& Sieg, 2018).

3 Total assets of pension funds at the end of January 2014 was 298.6 billion PLN while in February 2014 it was only 145.6 billion PLN. At the end of 2013, OFE assets equaled over 18\% of Polish GDP and $157 \%$ of all mutual fund assets. Polish GDP in 2013 equaled 1649.6 billion PLN and total assets of mutual funds were 189.9 billion PLN.
} 
2015 , the number of OFE members has decreased annually by $1 \%$. It means that after all the above-mentioned regulations, the share of the pension contribution transferred to the private pension investment funds decreased from 37.4\% (in the years 1999-2011) to 15\%, or even zero for the individual employee in the third quarter of 2014. It meant that OFE funds lost their importance in the creation of future pension benefits.

It is worth mentioning that in the public debate (started after the crisis) politicians did not provide any profound analysis, although there have been numerous studies concerning the efficiency of pension and mutual funds operating in Poland. The performance of OFEs and mutual funds has been investigated by: Ostrowska (2003), Chybalski (2006), Zamojska (2012), Otto and Wiśniewski (2013), Karpio and Żebrowska-Suchodolska (2016), Kompa and Witkowska (2015a, 2015b), Kompa and Wiśniewski (2015), Witkowska (2009, 2016), Mentel and Horvathova (2016); Mentel, Brożyna, Szetela, and Kompa (2016), Mentel, Brożyna, and Szetela (2017), Kurach (2017) among others ${ }^{4}$. Analyses were conducted for different time spans, sample lengths, various frequencies of observations, and a variety of efficiency measures. However, there is limited research comparing the efficiency of pension and mutual funds (for instance, Kompa \& Witkowska, 2016; Witkowska \& Kompa, 2017).

Therefore, the presented study aims to fill this gap in the literature, and two, unique and absolutely original, aims of the research have been distinguished. The first one is to find out if pension investment fund (OFE) performance was worse than the performance of mutual funds (FIO) which provide a similar investment policy, and which are represented by stable growth mutual funds. The second aim is to verify if the above-mentioned modifications to the pension system affected the efficiency of the selected mutual stable growth funds. To achieve these goals, the performance of stable growth mutual funds in particular time spans is assessed and compared to the performance of pension funds. Both aims are to check whether the Polish government had a real economic justification for the capital, structural and organizational manipulations made with respect to pension funds, or whether it was guided by the ad hoc premises of the budget deficit. The analysis was conducted by applying statistical inference, Sharpe and capital assets pricing models, together with classic investment efficiency ratios.

After this brief introductory section, Section 1 discusses the development of the investment funds in Poland, Section 2 describes data and methodology used in presented research, Sections 3, 4 and 5 contain empirical analysis of mutual and pension funds' performance in terms of rates of return, risk and efficiency measures, whereas the last section concludes.

\section{The development of mutual and pension funds in Poland}

Collective investment funds play an important role in the financial market since they mobilize savings and transmit them to the investments, i.e., the capital needed in the economy. Mutual and pension funds construct investment portfolios using savings obtained from individual investors. In Poland, the financial market started to develop in the 1990s, therefore, on the one hand, it had to catch up with highly developed economies and, on the other hand,

\footnotetext{
${ }^{4}$ Pension plans and performance of pension funds are subjects of research in many countries (Jame, 2010; Akpinar, 2014; Dybał, 2017; Tripathy, 2017; Boon, Brière, \& Rigot, 2018; Ngugi \& Njuguna, 2018).
} 
new technology and products appeared on the Polish financial market from the very beginning. However, there was still a mental barrier that made people keep their savings mostly in banks. According to the report of the National Bank of Poland (National Bank of Poland, 2018, pp. 12-16), an analysis of financial institutions and markets of various countries against the backdrop of their economic development implies that some segments of Poland's financial system still remain relatively poorly developed since assets of the financial system was only $124.4 \%$ of GDP while $475.7 \%$ in Euro area, and the system in Poland is bank dominated. The composition of the financial system by the value of assets at the end of 2017 consists of credit institutions (72.2\%), investment funds (12.2\%), insurance companies (8.0\%), pension funds $(7.3 \%)$, and other financial sector institutions $(0.3 \%)$.

One should realize that participation in mutual funds has always been voluntary in Poland whereas private pension funds created the mandatory capital-funded pillar in the reformed pension system. Thus, pension fund participation was obligatory for all employees until August 2014. Therefore, the dynamic of the assets increasing in both types of funds was different, and it changed diametrically in 2014.

The pension investment funds market in Poland developed dynamically and systematically until 2013; however, there were some disturbances in the growth of the OFEs' assets e.g. in 2008 , when pension fund assets decreased by $1.2 \%$ because of the subprime crisis and its consequences. Fortunately, due to very conservative investment restrictions concerning the essential share of risk-free instruments in their portfolios, OFEs in Poland lost much less than pension funds in more developed financial markets. Nevertheless, the annual dynamics of assets was $42 \%$ in the years 1999-2013. By contrast, in 2014, pension funds lost $50.18 \%$ of their assets (in comparison with the previous year) because, following a political decision, $51.5 \%$ of their assets were transferred to FUS. In 2014, the Polish government also abolished the obligation to collect pension contribution in OFEs. Therefore, in 2015, pension fund net assets decreased by another $5.77 \%$. It made the average annual increase of pension fund assets during the 19 years of their functioning 27.2\%, while in 2017 the value of assets had increased nearly 77 times from 1999.

Mutual fund assets increased systematically until 2007 by, on average, 60 percent annually. In 2008, they lost $43.5 \%$ of their assets because of the financial crisis, and another decrease of the FIOs' assets was observed in 2011, by 4.25\%. In general, in the years 1999-2017, the average annual increase of mutual fund assets was $28 \%$, and mutual fund assets increased 89 times in the considered time span. However, in the years 1999-2013, the average annual growth of FIO assets was smaller (33.8\%) than those of OFEs. Additionally, pension fund asset losses caused by the financial crises were much smaller than the losses of mutual funds.

\section{Description of data and methods}

An investigation is provided for daily, weekly and monthly logarithmic rates of returns of selected financial instruments. The time span is seven years, from 1.01.2009 to 31.12.2015 and is denoted by the letter a. The whole period of analysis is divided into six sub-periods of similar lengths of corresponding pairs of samples according to the three, already described, events that essentially changed the functioning of the pension funds: 
1) the decrease of the contribution transferred to OFE let us distinguish the following periods: (b) from 1.01.2009 to 30.04.2011 - before the event, and (c) from 1.05.2011 to 31.08.2013 - after the considered event (28 months for each sub-period);

2) the transfer of $51.5 \%$ of assets from OFE to FUS let us distinguish periods before and after this event, which are denoted by: (d) from 1.04.2012 to 31.01.2014 and (e) from 1.02.2014 to 31.12.2015 (22 and 23 months respectively),

3 ) the abolition of the obligatory membership in OFE let us distinguish the last pair of periods: (f) from 1.01.2013 to 30.06.2014 and (g) from 1.07.2014 to 31.12.2015 (18 months each).

Analyses are provided using daily observations of:

1) the participation units of ten stable growth open investment funds, namely: Allianz, Aviva, Credit Agricole, MetLife, Millennium, Nationale-Nederlanden, Pekao, Paribas, $\mathrm{PKO}$ and PZU;

2) the accounting units of selected OFE funds - managed by the same Investment and Pension Funds Companies as the mutual funds (under consideration) i.e. Allianz, Aviva, Nationale-Nederlanden, PKO, Pekao and PZU;

3) the Warsaw Stock Exchange Index (WIG), representing the situation on the capital market;

4) the interest rates of three-month and one-year loans - the Warsaw Interbank Offered Rate (WIBOR 3M and WIBOR 1Y), and Poland's Official Treasury Bonds Index (TBSP.Index), which are treated as risk-free instruments.

All data are taken from the websites stooq.pl, bankier.pl, biznesradar.pl and gpwinfostrefa.pl. WIG, TBSP indexes and WIBOR interest rate represent the capital, treasury bond and money markets, respectively, therefore they are used as benchmarks ${ }^{5}$ in provided investigations.

To compare the performance of selected mutual and pension funds the statistical inference and efficiency measures have been applied. The analysis of returns and risk, generated by the investment portfolios, is conducted using statistical tests concerning:

1) rates of return, namely to verify the following null hypotheses:

$-\mathrm{E}\left(\mathrm{R}_{\mathrm{OFE}}\right)=0 ; \mathrm{E}\left(\mathrm{R}_{\mathrm{FIO}}\right)=0$ and $\mathrm{E}\left(\mathrm{R}_{\text {benchmark }}\right)=0$, using test statistics $t$ or $u$ depending on the number of observations in the sample:

$$
t=\frac{R_{k}}{S_{k}} \sqrt{T_{k}-1} \text { or } u=\frac{R_{k}}{S_{k}} \sqrt{T_{k}} ;
$$

$-\mathrm{E}\left(\mathrm{R}_{\mathrm{OFE}}\right)=\mathrm{E}\left(\mathrm{R}_{\mathrm{FIO}}\right)$ and $\mathrm{E}\left(\mathrm{R}_{\text {before }}\right)=\mathrm{E}\left(\mathrm{R}_{\mathrm{after}}\right)$ applying the Cochran-Cox test with test $t$ or $u$ statistics depending on the number of observations in the sample:

$$
t=\frac{R_{1}-R_{2}}{\sqrt{\frac{T_{1} S_{1}^{2}+T_{2} S_{2}^{2}}{T_{1}+T_{2}-2}\left(\frac{1}{T_{1}}+\frac{1}{T_{2}}\right)}} \quad \text { or } \quad u=\frac{R_{1}-R_{2}}{\sqrt{\frac{S_{1}^{2}}{T_{1}}+\frac{S_{2}^{2}}{T_{2}}}} .
$$

\footnotetext{
5 It is worth mentioning that WIG and WIBOR are used to calculate the benchmarks, which have been officially used to evaluate pension fund efficiency since 2014 (Dziennik Ustaw, 2014).
} 
2) risk by confirming the null hypotheses $D^{2}\left(R_{\mathrm{OFE}}\right)=D^{2}\left(R_{\mathrm{FIO}}\right)$ and $D^{2}\left(R_{\text {before }}\right)=$ $D^{2}\left(R_{\text {after }}\right)$ using Fisher statistics:

$$
F=\frac{S_{\max }^{2}}{S_{\min }^{2}} ;
$$

3) the parameters of single index (Sharpe) and capital assets pricing models (CAPM), i.e., the null hypotheses, are formulated as:

$-\beta=0 ; \alpha=0$, and the test statistics are defined as:

$$
t=\frac{\hat{\alpha}_{i}}{S\left(\hat{\alpha}_{i}\right)} \text { and } t=\frac{\hat{\beta}_{i}}{S\left(\hat{\beta}_{i}\right)} ;
$$

$-\beta_{\mathrm{OFE}}=\beta_{\mathrm{FIO}}$ and $\beta_{\text {before }}=\beta_{\text {after }} ; \alpha_{\mathrm{OFE}}=\alpha_{\mathrm{FIO}}$ and $\alpha_{\text {before }}=\alpha_{\mathrm{after}}$ using two-way test statistics:

$$
\begin{aligned}
& t_{1}=\frac{\hat{\alpha}_{1 i}-\hat{\alpha}_{2 i}}{S\left(\hat{\alpha}_{1 i}\right)} \text { and } t_{2}=\frac{\hat{\alpha}_{1 i}-\hat{\alpha}_{2 i}}{S\left(\hat{\alpha}_{2 i}\right)} \\
& t_{1}=\frac{\hat{\beta}_{1 i}-\hat{\beta}_{2 i}}{S\left(\hat{\beta}_{1 i}\right)} \text { and } t_{2}=\frac{\hat{\beta}_{1 i}-\hat{\beta}_{2 i}}{S\left(\hat{\beta}_{2 i}\right)}
\end{aligned}
$$

where, $E(R)$ - expected returns, $D^{2}(R)$ - variance of returns, $R_{\mathrm{OFE}}, R_{\mathrm{FIO}}, R_{\text {benchmark }}-$ returns from OFE, FIO and benchmark respectively, $\beta, \alpha$ - parameters of the Sharpe model or CAPM, $R_{\text {before }}, R_{\text {after }}, \beta_{\text {before }} \beta_{\text {after }}$ - returns from the portfolio and beta coefficients before and after the change went into effect, respectively, $R_{k}$ - the average rate of return observed in the $k$-th sample (i.e. period or portfolio), $S_{k}^{2}$ - variance of rates of return from the $k$-th sample, $T_{k}$ - count of observations in the $k$-th sample $(k=1,2)$, $S_{\max }^{2}=\max \left\{S_{1}^{2}, S_{2}^{2}\right\}, \hat{\alpha}_{k i}, \hat{\beta}_{k i}-$ parameter estimates, $S\left(\hat{\alpha}_{k i}\right), S\left(\hat{\beta}_{k i}\right)$ - standard estimation errors, $t$ - $\mathrm{t}$-Student statistics, $u$ - statistics $\mathrm{N}(0,1), F$ - Fisher statistics. In the tables where the results of the statistical tests are presented, italic numbers denote rejection of the null hypothesis, assuming a significance level of 0.05 .

The comparison of fund efficiency is provided applying classic measures:

- the Sharpe ratio (Sharpe, 1966):

$$
W S_{i}=\frac{R_{i}-R_{f}}{S_{i}},
$$

- the Treynor ratio (Treynor, 1965):

$$
W T_{i}=\frac{R_{i}-R_{f}}{\hat{\beta}_{i}} ;
$$

- the Jensen ratio (Jensen 1968, 1969), which is the parameter estimate of alpha in CAPM:

$$
\hat{\alpha}_{i}=\left(R_{i}-R_{f}\right)+\hat{\beta}_{i}\left(R_{m}-R_{f}\right),
$$

where, $R_{i}, R_{f}, R_{m}$ - the average rate of return from the $i$-th portfolio, risk-free instrument and market index, respectively, $S_{i}$, - standard deviation of returns from the $i$-th portfolio, 
$\hat{\beta}_{i}$ - beta coefficient estimates from the single index or capital asset pricing model (CAPM). It is assumed that $R_{m t}=R_{W I G}$ and $R_{f t}=R_{\text {WIBOR } 3 M}, R_{f t}=R_{\text {WIBOR } 1 Y}$ or $R_{f t}=R_{T-}$ $B S P$. The efficiency ratios are evaluated for all considered pension and mutual funds in all analyzed intervals of returns, time spans, and for differently defined risk-free instruments.

\section{Analysis of rates of return and risk of mutual and pension funds}

In presented study, rates of return evaluated for all financial instruments are taken into consideration. Analysis is provided for three intervals of rates of return, i.e., (1) daily, (2) weekly, defined as a return obtained on Friday from an investment made on Monday, and (3) monthly, i.e., a return from the investment starting on the first day of the month and ending on the last day of the month in question ${ }^{6}$. It is worth mentioning that daily returns from these instruments were characterized by significant asymmetry and were leptokurtic, weekly rates of return were less asymmetric and leptokurtic, whereas monthly returns can be treated as normally distributed since they were symmetric with kurtosis not significantly different from zero, see (Witkowska, 2016; Kompa, 2018). Therefore, for big samples (i.e. daily and weekly returns), the central limit theorem is applied while for the small samples (the monthly returns) test statistics which required a normal distribution of sample elements are used.

Table 1. Values of the test statistic (1) verifying the hypothesis that returns from the benchmarks equal zero (source: own calculations)

\begin{tabular}{|l|c|c|c|c|c|c|c|}
\hline \multirow{2}{*}{ Benchmarks } & \multicolumn{7}{|c|}{ Periods: } \\
\cline { 2 - 9 } & $\mathrm{a}$ & $\mathrm{b}$ & $\mathrm{c}$ & $\mathrm{d}$ & $\mathrm{e}$ & $\mathrm{f}$ & $\mathrm{g}$ \\
\hline & \multicolumn{7}{|c|}{ Daily returns } \\
\hline TBSP & 5.45 & 2.87 & 3.78 & 2.40 & 2.87 & 1.47 & 1.62 \\
\hline WIG & 1.01 & 1.70 & -0.08 & 1.03 & -0.46 & 0.49 & -0.66 \\
\hline WIBOR3M & 135.25 & 299.29 & 132.83 & 81.51 & 109.28 & 137.22 & 116.34 \\
\hline WIBOR1Y & 134.20 & 383.60 & 128.40 & 82.30 & 112.90 & 160.50 & 126.50 \\
\hline & \multicolumn{7}{|c|}{ Weekly returns } \\
\hline TBSP & 4.23 & 1.69 & 3.44 & 1.94 & 2.39 & 1.10 & 1.30 \\
\hline WIG & 0.79 & 0.91 & 0.49 & 0.94 & -0.11 & 0.38 & -0.41 \\
\hline WIBOR3M & 60.55 & 133.70 & 59.23 & 36.30 & 48.54 & 60.59 & 51.32 \\
\hline WIBOR1Y & 60.09 & 171.70 & 57.26 & 36.60 & 50.11 & 70.82 & 55.75 \\
\hline & \multicolumn{7}{|c|}{ Monthly returns } \\
\hline TBSP & 4.53 & 2.42 & 2.73 & 1.74 & 2.85 & 1.12 & 1.62 \\
\hline WIG & 0.96 & 1.29 & -0.06 & 0.99 & -0.14 & 0.83 & -0.65 \\
\hline WIBOR3M & 28.83 & 69.78 & 27.24 & 16.90 & 23.32 & 27.44 & 23.10 \\
\hline WIBOR1Y & 28.61 & 85.19 & 26.32 & 17.00 & 24.10 & 31.69 & 24.87 \\
\hline
\end{tabular}

\footnotetext{
$\overline{6}$ All missing data were inputted as the last observation before the missing one.
} 
It is visible in Table 1 that returns from the WIG market index did not significantly differ from zero, regardless the type of return. However, after all the changes in the functioning of pension funds, the average returns from WIG are negative while for other periods they are positive. Nevertheless, these differences of returns seem not to be statistically significant (Table 2). The WIBOR_3M and WIBOR_1Y interest rates generated significantly positive returns in all periods (but their returns and volatility are very small) and they usually significantly decreased after changes in the pension systems (the opposite tendency is visible for the WIBOR_3M daily and weekly returns, after the decreasing pension contribution transferred to OFE). The TBSP index generates significantly positive returns except for last two periods. Taking into consideration the risk in comparing periods, the results show (Table 2) decisions about decreasing the pension contribution transferred to OFE and shifting the majority of OFE assets to FUS, together with the prohibition of having Treasury Bonds in pension fund portfolios, caused a significant increase in risk.

In the first step of the returns analysis of the mutual funds, it is checked whether the rates of return are significantly positive or negative. All results were collected in tabular form. The following abbreviations have been used: CA is an abbreviation of Credit Agricole, Mill - of Millennium and NN - of Nationale-Nederlanden.

Table 2. Values of statistics (2), (3) verifying equality of returns and risks in two comparing periods (source: own calculations)

\begin{tabular}{|l|c|c|c|c|c|c|}
\hline \multirow{3}{*}{ Benchmark } & \multicolumn{6}{|c|}{ Periods } \\
\cline { 2 - 7 } & $\mathrm{b}: \mathrm{c}$ & $\mathrm{d}: \mathrm{e}$ & $\mathrm{f}: \mathrm{g}$ & $\mathrm{b}: \mathrm{c}$ & $\mathrm{d}: \mathrm{e}$ & $\mathrm{f}: \mathrm{g}$ \\
\cline { 2 - 7 } & \multicolumn{7}{|c|}{ Comparison of average rates of return } & \multicolumn{7}{c|}{ Comparison of variances } \\
\hline TBSP & -0.99 & -0.08 & 0.05 & 1.36 & 1.26 & 1.34 \\
\hline WIG & 1.36 & 1.07 & 0.80 & 1.41 & 1.13 & 1.24 \\
\hline WIBOR3M & -5.76 & 33.24 & 36.17 & 5.64 & 5.55 & 1.61 \\
\hline WIBOR1Y & 2.68 & 32.56 & 39.49 & 8.61 & 5.54 & 1.35 \\
\hline & \multicolumn{7}{|c|}{ Daily returns } \\
\hline TBSP & -1.62 & -0.03 & -0.02 & 1.55 & 1.41 & 1.34 \\
\hline WIG & 0.40 & 0.76 & 0.56 & 1.53 & 1.11 & 1.16 \\
\hline WIBOR3M & -2.57 & 14.77 & 15.93 & 5.66 & 5.54 & 1.62 \\
\hline WIBOR1Y & 1.20 & 14.47 & 17.37 & 8.68 & 5.54 & 1.35 \\
\hline & \multicolumn{7}{|c|}{ Monthly returns } \\
\hline TBSP & -0.86 & -0.08 & 0.02 & 2.08 & 2.32 & 2.18 \\
\hline WIG & 1.06 & 0.90 & 1.05 & 1.64 & 2.17 & 1.52 \\
\hline WIBOR3M & -1.40 & 6.97 & 7.08 & 7.35 & 5.91 & 1.58 \\
\hline WIBOR1Y & 0.34 & 6.83 & 7.63 & 10.19 & 5.93 & 1.33 \\
\hline
\end{tabular}

It is discovered (Table 3 ) that the expected daily returns are significantly positive for all considered mutual funds (except FIO Allianz) only in period b, i.e., before the first change to 
the pension system, and for FIO Aviva, PKO, Nationale-Nederlanden and Credit Agricole in the periods denoted as a and d (i.e. in the whole period and before the most drastic intervention to the functioning of pension funds). One can also notice that negative returns usually appeared after the government interference.

Table 3. Values of statistic (1) verifying that daily returns from mutual funds in considered periods equal zero (source: own calculations)

\begin{tabular}{|l|c|c|r|r|r|r|r|}
\hline \multirow{2}{*}{$\begin{array}{c}\text { Mutual } \\
\text { Funds }\end{array}$} & \multicolumn{7}{|c|}{ Period } \\
\cline { 2 - 8 } & $\mathrm{a}$ & $\mathrm{b}$ & $\mathrm{c}$ & $\mathrm{d}$ & $\mathrm{e}$ & $\mathrm{f}$ & $\mathrm{g}$ \\
\hline Allianz & 0.08 & 0.56 & -0.18 & 0.16 & -0.60 & -0.20 & -0.86 \\
\hline AVIVA & 2.06 & 1.98 & 0.78 & 1.88 & 0.07 & 1.01 & -0.06 \\
\hline PKO & 2.18 & 1.89 & 0.89 & 1.87 & 0.59 & 1.00 & 0.15 \\
\hline NN & 1.78 & 1.85 & 0.65 & 1.66 & 0.29 & 0.65 & -0.25 \\
\hline Pekao & 0.30 & 1.69 & -1.08 & 0.65 & -0.31 & 0.11 & -0.59 \\
\hline PZU & 1.31 & 1.74 & 0.36 & 1.26 & -0.10 & 0.26 & -0.43 \\
\hline MetLife & 1.35 & 1.71 & 0.38 & 1.30 & -0.30 & 0.40 & -0.71 \\
\hline Paribas & 1.58 & 2.09 & -0.14 & 1.14 & 0.40 & 0.41 & -0.03 \\
\hline CA & 3.15 & 3.08 & 0.97 & 2.00 & 1.23 & 1.07 & 0.83 \\
\hline Mill & 1.24 & 1.87 & 0.13 & 1.22 & -0.46 & 0.29 & -0.48 \\
\hline Observations & 1823 & 604 & 610 & 480 & 499 & 390 & 393 \\
\hline
\end{tabular}

Taking into consideration the weekly and monthly rates of return (Tables 4, 5), we notice that there are even fewer significantly positive returns than for daily returns, since they are observed only for FIO Aviva (in periods a, b and d for weekly observations, together with periods a and $\mathrm{d}$ for monthly data), PKO (in periods $\mathrm{a}, \mathrm{b}$ and $\mathrm{d}$ for weekly observations, and in period a for monthly data), Paribas (in periods a and b for weekly observations and in period a for monthly data) and Credit Agricole (in periods a and b for weekly observations together with periods $\mathrm{a}, \mathrm{b}$ and $\mathrm{d}$ for monthly data). In general, significantly positive returns are observed for 34 of the 210 cases, i.e., in $16 \%$ of cases. Comparing the positive rates of returns generated by six investment companies which also managed pension funds (Tables $3-5)$, it is noticed that for 126 cases, pension funds obtained significantly positive returns in 21 cases $(24.6 \%)$ and mutual funds in 20 cases (15.9\%).

The application of the Cochran-Cox test to compare returns obtained by mutual funds in two comparable periods (i.e. before and after the modifications of the operating conditions of the pension funds) did not allow us to reject the null hypotheses while a comparison of the variances gives different results for mutual funds and periods (Table 6). The risk, measured by the variance of returns, significantly decreased in the period after government interference for all analyzed mutual funds, and it significantly increased only for daily returns from FIO Allianz in period e in comparison with period d. Considering the frequency of returns and all pairs of periods, it is visible that the decrease is visible the most often for FIO NationaleNederlanden (in 5 periods), together with Aviva and Pekao (in 5 periods), while Credit Agricole keeps the same level of risk for all samples except the ones from the last two periods 
for daily returns. In general, the decrease of risk in the second considered period is mostly visible for daily returns.

Table 4. Decisions based on statistics (1) for pension funds expected daily, weekly and monthly returns (source: own calculations)

\begin{tabular}{|c|c|c|c|c|c|c|c|c|c|c|c|c|c|c|c|c|c|c|c|c|c|}
\hline \multirow{3}{*}{ Returns } & \multicolumn{21}{|c|}{ Period } \\
\hline & $\mathrm{a}$ & $\mathrm{b}$ & c & $\mathrm{d}$ & e & $\mathrm{f}$ & g & $\mathrm{a}$ & $\mathrm{b}$ & c & $\mathrm{d}$ & e & $\mathrm{f}$ & g & $\mathrm{a}$ & $\mathrm{b}$ & c & d & e & $\mathrm{f}$ & g \\
\hline & \multicolumn{7}{|c|}{ daily } & \multicolumn{7}{|c|}{ weekly } & \multicolumn{7}{|c|}{ monthly } \\
\hline Allianz & + & + & 0 & + & 0 & 0 & 0 & 0 & 0 & 0 & 0 & 0 & 0 & 0 & + & + & 0 & + & 0 & 0 & 0 \\
\hline Aviva & + & + & 0 & + & 0 & 0 & 0 & 0 & 0 & 0 & 0 & 0 & 0 & 0 & + & + & 0 & + & 0 & 0 & 0 \\
\hline PKO & + & + & 0 & + & 0 & 0 & 0 & 0 & 0 & 0 & 0 & 0 & 0 & 0 & + & + & 0 & + & 0 & 0 & 0 \\
\hline NN & + & + & 0 & + & 0 & 0 & 0 & 0 & 0 & 0 & 0 & 0 & 0 & 0 & + & + & 0 & + & 0 & 0 & 0 \\
\hline Pekao & + & + & 0 & + & 0 & 0 & 0 & 0 & 0 & 0 & 0 & 0 & 0 & 0 & 0 & + & 0 & + & 0 & 0 & 0 \\
\hline PZU & + & + & 0 & + & 0 & 0 & 0 & + & + & 0 & + & 0 & 0 & 0 & 0 & + & 0 & 0 & 0 & 0 & 0 \\
\hline
\end{tabular}

Note: + denotes rejection of the null hypothesis for the alternative one about positive returns, 0 - the null cannot be rejected.

Table 5. Decisions based on statistics (1) for mutual funds expected weekly and monthly returns (source: own calculations)

\begin{tabular}{|c|c|c|c|c|c|c|c|c|c|c|c|c|c|c|}
\hline \multirow{2}{*}{$\begin{array}{l}\text { Mutual } \\
\text { Funds }\end{array}$} & \multicolumn{14}{|c|}{ Period } \\
\hline & a & $\mathrm{b}$ & c & $\mathrm{d}$ & $\mathrm{e}$ & $\mathrm{f}$ & $\mathrm{g}$ & $\mathrm{a}$ & $\mathrm{b}$ & c & $\mathrm{d}$ & $\mathrm{e}$ & $\mathrm{f}$ & $\mathrm{g}$ \\
\hline & \multicolumn{7}{|c|}{ Weekly returns } & \multicolumn{7}{|c|}{ Monthly returns } \\
\hline Allianz & 0 & 0 & 0 & 0 & 0 & 0 & 0 & 0 & 0 & 0 & 0 & 0 & 0 & 0 \\
\hline AVIVA & + & + & 0 & + & 0 & 0 & 0 & + & 0 & 0 & + & 0 & 0 & 0 \\
\hline PKO & + & + & 0 & + & 0 & 0 & 0 & + & 0 & 0 & 0 & 0 & 0 & 0 \\
\hline NN & 0 & 0 & 0 & 0 & 0 & 0 & 0 & 0 & 0 & 0 & 0 & 0 & 0 & 0 \\
\hline Pekao & 0 & 0 & 0 & 0 & 0 & 0 & 0 & 0 & 0 & 0 & 0 & 0 & 0 & 0 \\
\hline PZU & 0 & 0 & 0 & 0 & 0 & 0 & 0 & 0 & 0 & 0 & 0 & 0 & 0 & 0 \\
\hline MetLife & 0 & 0 & 0 & 0 & 0 & 0 & 0 & 0 & 0 & 0 & 0 & 0 & 0 & 0 \\
\hline Paribas & + & + & 0 & 0 & 0 & 0 & 0 & 0 & + & 0 & 0 & 0 & 0 & 0 \\
\hline CA & + & + & 0 & 0 & 0 & 0 & 0 & + & + & 0 & + & 0 & 0 & 0 \\
\hline Mill & 0 & 0 & 0 & 0 & 0 & 0 & 0 & 0 & 0 & 0 & 0 & 0 & 0 & 0 \\
\hline Observations & 364 & 121 & 122 & 96 & 99 & 78 & 78 & 84 & 28 & 28 & 22 & 23 & 18 & 18 \\
\hline
\end{tabular}

Note: + denotes rejection of the null hypothesis for the alternative one about positive returns; 0 - the null cannot be rejected. 
Table 6. Decisions based on statistics (2), (3) for returns and variances of mutual funds in the pairs of periods (source: own calculations)

\begin{tabular}{|c|c|c|c|c|c|c|c|c|c|c|c|c|c|c|c|c|c|c|}
\hline \multirow{3}{*}{ Periods } & \multicolumn{18}{|c|}{ Value of test statistic (source: own calculations) } \\
\hline & \multicolumn{9}{|c|}{ Cochran-Cox (2) for $H_{0}: E\left(R_{\text {before }}\right)=E\left(R_{\text {after }}\right)$} & \multicolumn{9}{|c|}{ Fisher (3) for $H_{0}: D^{2}\left(R_{\text {before }}\right)=D^{2}\left(R_{\text {after }}\right)$} \\
\hline & $b: c$ & d:e & f:g & $\mathrm{b}: \mathrm{c}$ & d:e & f:g & $\mathrm{b}: \mathrm{c}$ & d:e & f:g & $\mathrm{b}: \mathrm{c}$ & d:e & f:g & $\mathrm{b}: \mathrm{c}$ & d:e & f:g & $\mathrm{b}: \mathrm{c}$ & d:e & f:g \\
\hline Returns & \multicolumn{3}{|c|}{ daily } & \multicolumn{3}{|c|}{ weekly } & \multicolumn{3}{|c|}{ monthly } & \multicolumn{3}{|c|}{ daily } & \multicolumn{3}{|c|}{ weekly } & \multicolumn{3}{|c|}{ monthly } \\
\hline Allianz & 0 & 0 & 0 & 0 & 0 & 0 & 0 & 0 & 0 & - & + & 0 & - & 0 & 0 & 0 & 0 & 0 \\
\hline AVIVA & 0 & 0 & 0 & 0 & 0 & 0 & 0 & 0 & 0 & - & 0 & - & - & 0 & 0 & - & 0 & 0 \\
\hline PKO & 0 & 0 & 0 & 0 & 0 & 0 & 0 & 0 & 0 & 0 & - & 0 & 0 & 0 & 0 & 0 & - & 0 \\
\hline $\mathrm{NN}$ & 0 & 0 & 0 & 0 & 0 & 0 & 0 & 0 & 0 & - & - & - & - & 0 & 0 & 0 & - & 0 \\
\hline Pekao & 0 & 0 & 0 & 0 & 0 & 0 & 0 & 0 & 0 & 0 & - & - & 0 & 0 & - & 0 & - & 0 \\
\hline PZU & 0 & 0 & 0 & 0 & 0 & 0 & 0 & 0 & 0 & 0 & 0 & - & 0 & 0 & - & 0 & - & 0 \\
\hline MetLife & 0 & 0 & 0 & 0 & 0 & 0 & 0 & 0 & 0 & - & 0 & 0 & - & 0 & 0 & 0 & 0 & 0 \\
\hline Paribas & 0 & 0 & 0 & 0 & 0 & 0 & 0 & 0 & 0 & - & 0 & - & - & 0 & 0 & 0 & 0 & 0 \\
\hline $\mathrm{CA}$ & 0 & 0 & 0 & 0 & 0 & 0 & 0 & 0 & 0 & 0 & 0 & - & 0 & 0 & 0 & 0 & 0 & - \\
\hline Mill & 0 & 0 & 0 & 0 & 0 & 0 & 0 & 0 & 0 & - & 0 & - & - & 0 & 0 & 0 & 0 & 0 \\
\hline
\end{tabular}

Note: + and - denote rejection of the null hypothesis for the alternative one that risk in the second considered period increased or decreased, 0 - the null hypothesis cannot be rejected.

The next stage of the research consists of comparing the returns and risk generated by mutual and pension funds which were managed by the same investment companies. According to the results presented in Table 7, in 84 cases (66.7\%) pension funds obtained higher rates of return than stable growth funds, although there are only three cases when OFEs generated significantly bigger returns than FIOs. Such a situation occurred for OFE Allianz in period $\mathrm{d}, \mathrm{PKO}$ in $\mathrm{c}$ (daily returns) and PZU in $\mathrm{d}$ (weekly returns). It is worth mentioning that in the whole sample, and the periods before the changes to the rules for the functioning of OFEs, i.e., periods $b, d$ and $f$, pension funds usually generated bigger rates of returns than stable growth mutual funds, whereas the opposite is true for periods e and g, i.e., after the changes. Comparing risk (Table 8), we notice that pension fund portfolios were less risky than mutual fund investments, especially in periods e-g, while for samples b and c the risk generated by OFE portfolios was bigger. In general, in 69 cases (54.8\%), the risk of FIO was significantly bigger than OFE, while in 17 cases (13.5\%) the situation was the opposite.

Table 9 contains decisions made according to the values of the test statistics comparing expected returns and risk generated in two periods, i.e., before and after modification of the OFE environment. The null hypothesis for returns cannot be rejected in any case; however, the rates of return for pension funds were always bigger before than after the change, (Witkowska, 2016). In comparison with the six mutual funds managed by the same investment companies, it is observed that the situation is the same (Table 6). One may also notice that for all pension funds, risk evaluated as a variance (Table 9) of daily and weekly returns significantly increased in periods e and g, i.e., after the changes introduced by the government. In other cases, no significant changes of risk are observed. 
Table 7. Values of statistic (2) for the comparison of expected returns for FIO and OFE (source: own calculations)

\begin{tabular}{|c|c|c|c|c|c|c|c|}
\hline \multirow{2}{*}{ Periods } & \multirow{2}{*}{ Returns } & \multicolumn{6}{|c|}{ Values of test statistic (2) for $H_{0}: E\left(R_{\mathrm{FIO}}\right)=E\left(R_{\mathrm{OFE}}\right)$} \\
\hline & & Allianz & Aviva & NN & Pekao & $\mathrm{PKO}$ & $\mathrm{PZU}$ \\
\hline \multirow{3}{*}{ a } & Daily & 1.19 & -0.01 & 0.20 & 1.07 & 0.21 & 0.48 \\
\hline & Weekly & 0.63 & -0.29 & 0.18 & 0.37 & 0.23 & 0.79 \\
\hline & Monthly & 0.95 & -0.06 & 0.22 & 0.60 & 0.26 & 0.07 \\
\hline \multirow{3}{*}{$\mathrm{b}$} & Daily & 0.90 & -0.08 & 0.15 & 0.20 & 0.55 & 0.40 \\
\hline & Weekly & 0.40 & 0.00 & 0.38 & 0.21 & 0.56 & 1.38 \\
\hline & Monthly & 0.63 & 0.00 & 0.36 & 0.03 & 0.57 & 0.57 \\
\hline \multirow{3}{*}{ c } & Daily & 0.90 & 0.35 & 0.39 & 1.67 & 0.33 & 0.59 \\
\hline & Weekly & 0.25 & -0.38 & -0.10 & 0.64 & -0.08 & -0.01 \\
\hline & Monthly & 0.66 & 0.16 & 0.24 & 1.10 & 0.19 & 0.11 \\
\hline \multirow{3}{*}{ d } & Daily & 1.98 & 0.20 & 0.62 & 0.82 & 0.77 & 0.30 \\
\hline & Weekly & 0.97 & -0.06 & -0.03 & 0.22 & 0.16 & 2.68 \\
\hline & Monthly & 1.36 & 0.29 & 0.49 & 0.74 & 0.51 & 0.29 \\
\hline \multirow{3}{*}{ e } & Daily & 0.26 & -0.34 & -0.43 & -0.15 & -0.23 & 0.05 \\
\hline & Weekly & 0.26 & -0.05 & -0.22 & -0.12 & -0.17 & -0.23 \\
\hline & Monthly & 0.17 & -0.29 & -0.55 & -0.39 & -0.38 & -0.69 \\
\hline \multirow{3}{*}{$\mathrm{f}$} & Daily & 0.80 & 0.08 & 0.29 & 0.54 & 0.21 & 0.41 \\
\hline & Weekly & 0.39 & -0.15 & 0.25 & 0.19 & 0.22 & 0.75 \\
\hline & Monthly & 0.86 & 0.06 & 0.42 & 0.50 & 0.36 & 0.17 \\
\hline \multirow{3}{*}{ g } & Daily & 0.09 & -0.27 & -0.45 & -0.28 & -0.36 & -0.07 \\
\hline & Weekly & 0.17 & -0.17 & -0.15 & -0.14 & -0.25 & -0.34 \\
\hline & Monthly & 0.14 & -0.41 & -0.48 & -0.42 & -0.40 & -0.47 \\
\hline
\end{tabular}

Note: positive values of statistics denote that returns from OFEs are bigger than from FIOs.

Table 8. Decisions based on statistics (3) for the risk comparison of OFE and FIO; $\mathrm{H}_{0}: \mathrm{D}^{2}\left(\mathrm{R}_{\mathrm{OFE}}\right)=$ $\mathrm{D}^{2}\left(\mathrm{R}_{\mathrm{FIO}}\right)$ (source: own calculations)

\begin{tabular}{|c|c|c|c|c|c|c|c|c|c|c|c|c|c|c|c|c|c|c|c|c|c|}
\hline \multirow{3}{*}{ Returns } & \multicolumn{21}{|c|}{ Periods } \\
\hline & $\mathrm{a}$ & $\mathrm{b}$ & c & $\mathrm{d}$ & $\mathrm{e}$ & $\mathrm{f}$ & $\mathrm{g}$ & $\mathrm{a}$ & $\mathrm{b}$ & c & $\mathrm{d}$ & $\mathrm{e}$ & $\mathrm{f}$ & $\mathrm{g}$ & $\mathrm{a}$ & $\mathrm{b}$ & c & $\mathrm{d}$ & $\mathrm{e}$ & $\mathrm{f}$ & g \\
\hline & \multicolumn{7}{|c|}{ daily } & \multicolumn{7}{|c|}{ weekly } & \multicolumn{7}{|c|}{ monthly } \\
\hline Allianz & - & - & - & + & + & + & + & + & - & 0 & + & + & + & + & 0 & - & 0 & 0 & + & 0 & + \\
\hline Aviva & + & - & 0 & + & + & + & + & + & - & 0 & + & + & + & + & 0 & 0 & 0 & 0 & + & 0 & + \\
\hline $\mathrm{NN}$ & + & - & - & + & + & + & + & + & 0 & 0 & + & + & + & + & 0 & 0 & 0 & 0 & + & 0 & + \\
\hline Pekao & + & - & - & - & + & + & + & + & - & - & 0 & + & + & + & 0 & - & 0 & 0 & + & 0 & + \\
\hline PKO & + & 0 & 0 & + & + & + & + & + & 0 & 0 & + & + & + & + & + & 0 & 0 & 0 & + & 0 & + \\
\hline $\mathrm{PZU}$ & + & 0 & - & - & + & 0 & + & + & 0 & 0 & + & + & + & + & + & 0 & 0 & 0 & + & 0 & + \\
\hline
\end{tabular}

Note: + and - denote rejection of null hypothesis for the alternative one that risk of FIO is bigger or smaller than the risk of OFE, respectively, 0 - the null hypothesis cannot be rejected. 
Table 9. Decisions based on statistics (2), (3) for returns and variances of pension funds in the pairs of periods (source: own calculations)

\begin{tabular}{|c|c|c|c|c|c|c|c|c|c|c|c|c|c|c|c|c|c|c|}
\hline \multirow{4}{*}{$\begin{array}{l}\text { Returns } \\
\text { Periods }\end{array}$} & \multicolumn{18}{|c|}{ Value of test statistic } \\
\hline & \multicolumn{9}{|c|}{ Cochran-Cox (2) for $H_{0}: E\left(R_{\text {before }}\right)=E\left(R_{\text {after }}\right.$} & \multicolumn{9}{|c|}{ Fisher (3) for $H_{0}: D^{2}\left(R_{\text {before }}\right)=D^{2}\left(R_{\text {after }}\right)$} \\
\hline & \multicolumn{3}{|c|}{ Daily } & \multicolumn{3}{|c|}{ Weekly } & \multicolumn{3}{|c|}{ Monthly } & \multicolumn{3}{|c|}{ Daily } & \multicolumn{3}{|c|}{ Weekly } & \multicolumn{3}{|c|}{ Monthly } \\
\hline & $\mathrm{b}: \mathrm{c}$ & d:e & $\mathrm{f}: \mathrm{g}$ & $\mathrm{b}: \mathrm{c}$ & d:e & $\mathrm{f}: \mathrm{g}$ & $b: c$ & d:e & f:g & $\mathrm{b}: \mathrm{c}$ & d:e & $\mathrm{f:g}$ & $\mathrm{b}: \mathrm{c}$ & $\mathrm{d}: \mathrm{e}$ & f:g & $\mathrm{b}: \mathrm{c}$ & d:e & f:g \\
\hline Allianz & 0 & 0 & 0 & 0 & 0 & 0 & 0 & 0 & 0 & 0 & + & + & 0 & + & + & 0 & 0 & 0 \\
\hline Aviva & 0 & 0 & 0 & 0 & 0 & 0 & 0 & 0 & 0 & 0 & + & + & 0 & + & + & 0 & 0 & 0 \\
\hline NN & 0 & 0 & 0 & 0 & 0 & 0 & 0 & 0 & 0 & 0 & + & + & 0 & + & + & 0 & 0 & 0 \\
\hline Pekao & 0 & 0 & 0 & 0 & 0 & 0 & 0 & 0 & 0 & 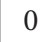 & + & + & 0 & + & + & 0 & 0 & 0 \\
\hline PKO & 0 & 0 & 0 & 0 & 0 & 0 & 0 & 0 & 0 & 0 & + & + & 0 & + & + & 0 & 0 & 0 \\
\hline $\mathrm{PZU}$ & 0 & 0 & 0 & 0 & 0 & 0 & 0 & 0 & 0 & 0 & + & + & 0 & + & + & 0 & 0 & 0 \\
\hline
\end{tabular}

Note: + and - denote rejection of the null hypothesis for the alternative one that risk in the second considered period increased or decreased, respectively, while 0 - the null hypothesis cannot be rejected.

\section{Comparison of beta coefficients}

The beta coefficient from the single index or capital asset pricing models is treated as a measure of risk. Both models are estimated under several assumptions concerning: (1) the interval for the rates of return evaluation, (2) the selection of the market index, (3) the selection of the risk-free instruments and (4) the estimation period. In our analysis, 84 models describing returns from the investment portfolios of each considered mutual and pension fund were estimated. These models differed in:

- their construction: Sharpe models using WIG as the market index and CAPM evaluated for three variants of risk-free instruments, i.e., TBSP, WIBOR 3M and WIBOR 1Y;

- the period of analysis: seven distinguished periods a-g;

- the frequency of data: daily, weekly and monthly.

However, in this paper, only some results will be discussed ${ }^{7}$. It is worth mentioning that the beta coefficients in all models estimated for the pension and mutual funds are significantly positive (except for the models estimated for OFE PZU in periods a, b, e, f and g, when they do not significantly differ from zero (Witkowska, 2016)).

The parameter estimates of beta and the determination coefficients in the single index models, and the capital assets pricing models with WIBOR as the risk-free instrument, are almost of the same values, whereas using TBSP as the risk-free instrument gives slightly different values of beta for all models estimated for pension and mutual funds. Therefore, in the further analysis, the single index model and CAPM with TBSP as the risk-free instrument will be used.

\footnotetext{
$\overline{7 \text { Detailed results are }}$ presented in Witkowska (2016) and Kompa (2018).
} 
Table 10. Decision based on statistics (5) for equality of betas from single index (S) and capital assets pricing (C) models estimated for mutual funds in the considered periods (source: own calculations)

\begin{tabular}{|c|c|c|c|c|c|c|c|c|c|c|c|c|c|c|c|c|c|c|}
\hline \multirow{4}{*}{$\begin{array}{l}\text { Returns } \\
\text { Models }\end{array}$} & \multicolumn{18}{|c|}{ Periods } \\
\hline & \multicolumn{6}{|c|}{$\mathrm{b}: \mathrm{c}$} & \multicolumn{6}{|c|}{$\mathrm{d}: \mathrm{e}$} & \multicolumn{6}{|c|}{$f: g$} \\
\hline & \multicolumn{2}{|c|}{$\mathrm{D}$} & \multicolumn{2}{|c|}{$\mathrm{W}$} & \multicolumn{2}{|c|}{$M$} & \multicolumn{2}{|c|}{$\mathrm{D}$} & \multicolumn{2}{|c|}{$\mathrm{W}$} & \multicolumn{2}{|c|}{$\mathrm{M}$} & \multicolumn{2}{|c|}{$\mathrm{D}$} & \multicolumn{2}{|c|}{$\mathrm{W}$} & \multicolumn{2}{|c|}{$M$} \\
\hline & S & C & S & $\mathrm{C}$ & S & $\mathrm{C}$ & S & $\mathrm{C}$ & S & C & S & $\mathrm{C}$ & S & $\mathrm{C}$ & S & $\mathrm{C}$ & S & $\mathrm{C}$ \\
\hline Allianz & + & + & + & + & 0 & 0 & + & + & + & + & 0 & 0 & + & + & + & 0 & 0 & 0 \\
\hline AVIVA & - & - & - & - & - & - & + & + & + & + & 0 & 0 & + & + & 0 & 0 & 0 & 0 \\
\hline PKO & + & + & + & + & + & + & 0 & 0 & 0 & 0 & 0 & + & 0 & 0 & 0 & 0 & 0 & + \\
\hline $\mathrm{NN}$ & 0 & + & 0 & + & 0 & + & 0 & + & 0 & + & 0 & + & 0 & 0 & 0 & 0 & 0 & 0 \\
\hline Pekao & + & + & + & + & + & + & 0 & - & - & - & 0 & 0 & + & + & + & + & 0 & + \\
\hline PZU & + & + & + & + & + & + & 0 & + & 0 & 0 & 0 & + & + & + & + & + & + & + \\
\hline MetLife & - & - & - & - & 0 & 0 & - & - & - & - & - & - & + & + & + & 0 & 0 & 0 \\
\hline Paribas & + & + & 0 & 0 & 0 & 0 & + & + & + & + & + & + & + & + & 0 & + & 0 & 0 \\
\hline CA & + & + & + & + & 0 & 0 & 0 & 0 & 0 & 0 & 0 & 0 & 0 & + & 0 & 0 & 0 & 0 \\
\hline Mill & + & + & + & + & + & + & + & 0 & 0 & + & 0 & + & 0 & + & + & + & 0 & + \\
\hline
\end{tabular}

Note: + and - denote rejection of the null hypothesis for the alternative one that risk in the second considered period increased or decreased, respectively, 0 - the null hypothesis cannot be rejected; $\mathrm{D}$ means daily, $\mathrm{W}$ - weekly, $\mathrm{M}$ - monthly.

Table 10 contains information about changes of the portfolio risk, measured by beta coefficients. Risk decreased only for period c (in comparison with period b) for all six presented models estimated for FIO Aviva and FIO MetLife, but with the exception of models built for monthly data. However, this tendency is observed for all models estimated for periods $\mathrm{d}$ and $\mathrm{e}$, and for these periods the same tendency is also observed for the models estimated for FIO Pekao, using weekly data, and for the CAPM model estimated on the basis of daily frequencies. Risk increased in the second analyzed periods for FIO Allianz using daily and monthly returns (with the exception of CAPM estimated on weekly data in periods $f$ and g), FIO PZU and Millennium for the majority of cases. In general, the risk increased in the second considered period for 88 cases (48.9\%) and decreased for 19 cases (10.6\%), i.e., it did not change for 73 cases $(40.6 \%)$. The beta coefficient evaluated for the analyzed pension funds increased after changes in the functioning of the OFE for all pairs of periods and all intervals of returns, except OFE PZU for daily rates of return in periods b and $c$ when the risk significantly increased, and for CAPM estimated in periods $\mathrm{f}$ and $\mathrm{g}$ when the difference of betas does not significantly differ (Witkowska, 2016).

Betas from the models estimated for the pension and mutual funds are also compared. For daily returns (Table 11), betas for all pension funds in periods a-d are significantly smaller for OFE than for FIO in the majority of cases (except for PKO in a and Allianz in d). However, in sub-periods e-g, the situation is the opposite, except for PZU. For weekly or monthly returns, the tendency seems to be the same although the widening of the interval for the rates of return causes an increasing number of insignificant differences between both types of funds. 
Table 11. Decision based on statistics (5) for equality of betas estimated for the pension and mutual funds in all periods; $H_{0}: \beta_{\mathrm{OFE}}=\beta_{\mathrm{FIO}}$ (source: own calculations)

\begin{tabular}{|c|c|c|c|c|c|c|c|c|c|c|c|c|c|c|c|c|c|c|c|c|c|}
\hline \multirow{3}{*}{ Returns } & \multicolumn{21}{|c|}{ Periods } \\
\hline & $\mathrm{a}$ & $\mathrm{b}$ & c & $\mathrm{d}$ & e & $\mathrm{f}$ & g & $\mathrm{a}$ & $\mathrm{b}$ & c & $\mathrm{d}$ & $\mathrm{e}$ & $\mathrm{f}$ & g & $\mathrm{a}$ & $\mathrm{b}$ & c & $\mathrm{d}$ & e & $\mathrm{f}$ & $\mathrm{g}$ \\
\hline & \multicolumn{7}{|c|}{ daily } & \multicolumn{7}{|c|}{ weekly } & \multicolumn{7}{|c|}{ monthly } \\
\hline \multicolumn{22}{|c|}{ Sharpe model } \\
\hline Allianz & + & + & + & - & - & - & - & - & 0 & 0 & 0 & 0 & - & - & 0 & + & 0 & 0 & 0 & - & - \\
\hline AVIVA & + & + & + & 0 & - & - & - & - & + & + & 0 & 0 & - & - & 0 & + & 0 & 0 & 0 & - & - \\
\hline $\mathrm{PKO}$ & - & + & + & 0 & - & - & - & - & 0 & + & 0 & 0 & - & - & - & 0 & 0 & 0 & 0 & - & - \\
\hline NN & + & + & + & + & - & - & - & - & + & 0 & 0 & 0 & - & - & - & 0 & 0 & 0 & 0 & - & - \\
\hline Pekao & + & + & + & + & - & - & - & - & + & + & 0 & 0 & - & - & + & + & + & 0 & 0 & - & - \\
\hline PZU & + & + & + & + & + & + & + & + & + & + & 0 & 0 & + & - & - & 0 & 0 & 0 & 0 & 0 & - \\
\hline \multicolumn{22}{|c|}{ CAPM TBSP } \\
\hline Allianz & + & + & + & - & - & - & - & - & 0 & 0 & 0 & 0 & - & - & 0 & + & 0 & 0 & 0 & - & - \\
\hline AVIVA & + & + & + & 0 & - & - & - & - & + & + & 0 & 0 & - & - & 0 & + & - & 0 & 0 & - & - \\
\hline PKO & - & + & + & 0 & - & - & - & - & 0 & + & 0 & 0 & - & - & - & 0 & - & 0 & 0 & - & - \\
\hline NN & + & + & + & + & - & - & - & - & + & 0 & 0 & 0 & - & - & - & 0 & - & 0 & 0 & - & - \\
\hline Pekao & + & + & + & + & - & 0 & - & - & + & + & 0 & 0 & - & - & + & + & - & 0 & 0 & - & - \\
\hline PZU & + & + & + & + & + & + & + & + & + & + & 0 & 0 & + & - & - & 0 & 0 & 0 & 0 & 0 & - \\
\hline
\end{tabular}

Note: + and - denote rejection of the null hypothesis for the alternative one that beta of FIO is bigger or smaller than the risk of OFE, respectively, 0 - the null hypothesis cannot be rejected.

\section{Analysis of investment efficiency measures}

In this study, the classic efficiency measures are evaluated for all funds, data frequencies and samples. All calculations are made for three risk-free instruments (i.e. WIBOR 3M, WIBOR $1 Y$ and TBSP Index) and Treynor ratio is evaluated using betas from single index and capital assets pricing models. In other words, for each fund, period and interval of returns, the three Sharpe and Jensen ratios and six Treynor ratios are evaluated. Therefore, in the tables, the average values of these measures are presented (which are multiplied by 100 because their values were very small). Italic numbers denote values of Sharpe and Treynor ratios evaluated for mutual funds which are bigger than the ones calculated for the WIG market index.

One may notice in Table 12 that in the whole period of analysis there were only two mutual funds which are effective - Aviva and CA, i.e., they obtained Sharpe and Treynor ratios bigger than the ones evaluated for WIG, and the Jensen ratios were positive. It can also be mentioned the FIO MetLife, for which the Sharpe and Treynor ratios show efficiency for daily and weekly returns. PKO, NN, PZU and Paribas generated a positive risk premium, although the Jensen ratios equal zero or are negative. The worst mutual funds are Allianz, Pekao and Millennium, for which risk premiums and Jensen ratios are negative. 
Table 12. Average values of Sharpe, Treynor and Jensen efficiency ratios for mutual funds in whole period 2009-2015 (source: own calculations)

\begin{tabular}{|l|c|c|c|c|c|c|c|c|c|}
\hline \multirow{3}{*}{ Measure } & \multicolumn{9}{|c|}{ Returns } \\
\cline { 2 - 11 } & \multicolumn{3}{|c|}{ daily } & \multicolumn{3}{c|}{ weekly } & \multicolumn{3}{c|}{ monthly } \\
\cline { 2 - 11 } & $(6)$ & $(7)$ & $(8)$ & $(6)$ & $(7)$ & $(8)$ & $(6)$ & $(7)$ & $(8)$ \\
\hline Allianz & -2.59 & -0.04 & -0.02 & -4.04 & -0.12 & -0.05 & -9.05 & -0.57 & -0.28 \\
\hline AVIVA & 1.44 & 0.02 & 0.00 & 2.06 & 0.05 & 0.01 & 5.51 & 0.30 & 0.04 \\
\hline PKO & 0.92 & 0.01 & 0.00 & 0.45 & 0.01 & 0.00 & 4.19 & 0.23 & 0.00 \\
\hline NN & 0.71 & 0.01 & 0.00 & -0.62 & -0.02 & -0.02 & 1.88 & 0.09 & -0.05 \\
\hline Pekao & -2.39 & -0.03 & -0.02 & -4.33 & -0.10 & -0.05 & -6.57 & -0.36 & -0.26 \\
\hline PZU & 0.12 & 0.00 & -0.01 & 0.98 & 0.02 & 0.00 & 2.83 & 0.15 & -0.05 \\
\hline MetLife & 4.24 & 0.06 & 0.00 & -0.48 & -0.02 & -0.06 & 10.8 & 0.75 & -0.09 \\
\hline Paribas & 0.07 & 0.00 & 0.00 & 0.85 & 0.02 & 0.00 & 1.87 & 0.10 & -0.05 \\
\hline CA & 2.90 & 0.04 & 0.01 & 4.49 & 0.12 & 0.02 & 11.8 & 0.68 & 0.13 \\
\hline Mill & -0.74 & -0.01 & -0.01 & -2.30 & -0.05 & -0.03 & -4.25 & -0.24 & -0.15 \\
\hline
\end{tabular}

Before changes in the pension system (Table 13), there were only two effective mutual funds, FIO Paribas and Credit Agricole, although only two funds generated a negative risk premium for daily and weekly returns. In period c (Table 14), the market index generated a negative risk premium (Table 19), therefore, the majority of mutual funds are also characterized by a negative value of Sharpe and Treynor ratios, although FIO Aviva, PKO, NN, PZU and Credit Agricole obtained higher values of these measures than WIG. There are also more funds with a positive Jensen alpha than in period $b$.

Table 13. Average values of Sharpe, Treynor and Jensen efficiency ratios evaluated for mutual funds for period b (source: own calculations)

\begin{tabular}{|l|c|c|c|c|c|c|c|c|c|}
\hline \multirow{3}{*}{ Measure } & \multicolumn{9}{|c|}{ Returns } \\
\cline { 2 - 11 } & \multicolumn{3}{|c|}{ daily } & \multicolumn{3}{c|}{ weekly } & \multicolumn{3}{c|}{ monthly } \\
\cline { 2 - 11 } & $(6)$ & $(7)$ & $(6)$ & $(6)$ & $(6)$ & $(8)$ & $(6)$ & $(7)$ & $(6)$ \\
\hline Allianz & -0.07 & 0.00 & -0.02 & -0.82 & -0.03 & -0.05 & 1.68 & 0.14 & -0.40 \\
\hline AVIVA & 5.38 & 0.08 & 0.00 & 5.13 & 0.11 & -0.01 & 18.03 & 1.24 & -0.01 \\
\hline PKO & 3.91 & 0.05 & 0.00 & -0.41 & 0.00 & -0.07 & 11.08 & 0.71 & -0.13 \\
\hline NN & 4.60 & 0.06 & 0.00 & 0.82 & 0.02 & -0.05 & 13.87 & 0.82 & -0.11 \\
\hline Pekao & -7.25 & -0.10 & -0.01 & -6.20 & -0.15 & -0.04 & 16.09 & 1.16 & 0.02 \\
\hline PZU & 4.37 & 0.06 & -0.01 & 3.39 & 0.09 & -0.04 & 12.88 & 0.87 & -0.19 \\
\hline MetLife & 4.24 & 0.06 & 0.00 & -0.48 & -0.02 & -0.06 & 10.84 & 0.75 & -0.09 \\
\hline Paribas & 5.43 & 0.10 & 0.01 & 12.04 & 0.33 & 0.06 & 21.06 & 1.26 & 12.00 \\
\hline CA & 8.24 & 0.12 & 0.01 & 10.01 & 0.29 & 0.04 & 26.99 & 1.71 & 0.54 \\
\hline Mill & 4.37 & 0.05 & 0.00 & 0.84 & 0.01 & -0.04 & 12.46 & 0.67 & 0.34 \\
\hline
\end{tabular}


Table 14. Average values of Sharpe, Treynor and Jensen efficiency ratios evaluated for mutual funds for period c (source: own calculations)

\begin{tabular}{|l|c|c|c|c|c|c|c|c|c|}
\hline \multirow{3}{*}{ Measures } & \multicolumn{9}{|c|}{ Returns } \\
\cline { 2 - 11 } & \multicolumn{3}{|c|}{ daily } & \multicolumn{3}{c|}{ weekly } & \multicolumn{3}{c|}{ Monthly } \\
\cline { 2 - 11 } & $(6)$ & $(7)$ & $(6)$ & $(6)$ & $(6)$ & $(8)$ & $(6)$ & $(7)$ & $(6)$ \\
\hline Allianz & -3.99 & -0.05 & -0.01 & -3.63 & -0.09 & -0.04 & -16.12 & -0.96 & -0.26 \\
\hline AVIVA & -1.27 & -0.02 & 0.00 & 3.05 & 0.07 & 0.02 & -5.95 & -0.36 & 0.04 \\
\hline PKO & -1.11 & 0.03 & 0.00 & 1.89 & 0.53 & 0.01 & -3.98 & -0.05 & 0.06 \\
\hline NN & -1.52 & -0.02 & 0.00 & 1.94 & 0.04 & 0.01 & -6.71 & -0.38 & 0.02 \\
\hline Pekao & -7.94 & -0.10 & -0.03 & -9.07 & -0.21 & -0.08 & -28.00 & -1.50 & -0.57 \\
\hline PZU & -1.62 & -0.82 & 0.00 & 2.78 & 1.42 & 0.03 & -6.36 & -3.34 & 0.07 \\
\hline MetLife & -2.79 & -0.03 & 0.00 & -4.29 & -0.10 & -0.04 & -12.52 & -0.65 & 0.13 \\
\hline Paribas & -5.45 & -0.08 & -0.01 & -9.28 & -0.24 & -0.07 & -22.15 & -1.35 & -0.31 \\
\hline CA & -1.20 & -0.02 & 0.00 & 1.49 & 0.04 & 0.01 & -6.42 & -0.42 & 0.00 \\
\hline Mill & -3.81 & -0.05 & -0.01 & -2.76 & -0.06 & -0.02 & -15.79 & -0.83 & -0.15 \\
\hline
\end{tabular}

Table 15. Average values of Sharpe, Treynor and Jensen efficiency ratios evaluated for mutual funds for period d (source: own calculations)

\begin{tabular}{|l|c|c|c|c|c|c|c|c|c|}
\hline \multirow{3}{*}{ Measure } & \multicolumn{9}{|c|}{ Returns } \\
\cline { 2 - 11 } & \multicolumn{3}{|c|}{ daily } & \multicolumn{3}{c|}{ weekly } & \multicolumn{3}{c|}{ monthly } \\
\cline { 2 - 11 } & $(6)$ & $(7)$ & $(6)$ & $(6)$ & $(6)$ & $(8)$ & $(6)$ & $(7)$ & $(6)$ \\
\hline Allianz & -4.58 & -0.05 & -0.02 & -8.86 & -0.19 & -0.08 & -17.36 & -0.83 & -0.41 \\
\hline AVIVA & 3.79 & 0.04 & 0.00 & 6.27 & 0.14 & 0.01 & 15.50 & 0.84 & 0.09 \\
\hline PKO & 3.44 & 0.04 & 0.01 & 6.48 & 0.14 & 0.00 & 14.31 & 1.85 & 0.04 \\
\hline NN & 3.26 & 0.03 & 0.00 & 6.44 & 0.13 & 0.01 & 11.70 & 0.58 & 0.00 \\
\hline Pekao & -0.89 & -0.01 & -0.01 & -0.18 & 0.00 & -0.04 & -3.08 & -0.10 & -0.28 \\
\hline PZU & 4.52 & 0.04 & 0.01 & 8.86 & 12.68 & -0.01 & 19.46 & 0.86 & 0.20 \\
\hline MetLife & 1.33 & 0.01 & -0.01 & 0.68 & 0.01 & -0.03 & 4.32 & 0.21 & 0.04 \\
\hline Paribas & 0.66 & 0.01 & -0.01 & -2.15 & -0.05 & -0.05 & 1.33 & 0.06 & -0.16 \\
\hline CA & 4.08 & 0.05 & 0.00 & 5.33 & 0.13 & 0.01 & 15.54 & 0.91 & 0.09 \\
\hline Mill & 1.15 & 0.01 & -0.01 & 3.51 & 0.07 & -0.01 & 5.75 & 0.26 & -0.13 \\
\hline
\end{tabular}

In period d (Table 15), all mutual funds except for FIO Allianz and Pekao generated a positive risk premium; however, the effective funds are Aviva, PKO, NN, PZU and CA. After transferring the majority assets from OFE to ZUS (Table 16), there are only three mutual funds which obtained a positive risk premium for at least one rate of return interval, i.e., Credit Agricole (for all data frequencies), Paribas and PKO, although FIO Aviva and NN seem to be effective. 
Table 16. Average values of Sharpe, Treynor and Jensen efficiency ratios evaluated for mutual funds for period e (source: own calculations)

\begin{tabular}{|l|c|c|c|c|c|c|c|c|c|}
\hline \multirow{3}{*}{ Measure } & \multicolumn{9}{|c|}{ Returns } \\
\cline { 2 - 11 } & \multicolumn{3}{|c|}{ daily } & \multicolumn{3}{c|}{ weekly } & \multicolumn{3}{c|}{ monthly } \\
\cline { 2 - 11 } & $(6)$ & $(7)$ & $(8)$ & $(6)$ & $(7)$ & $(8)$ & $(6)$ & $(7)$ & $(8)$ \\
\hline Allianz & -6.75 & -0.06 & -0.01 & -9.87 & -0.19 & -0.04 & -29.84 & -1.01 & -0.22 \\
\hline AVIVA & -3.59 & -0.04 & 0.00 & -3.89 & -0.08 & 0.00 & -12.16 & -0.45 & -0.04 \\
\hline PKO & -1.85 & -0.02 & 0.00 & 0.47 & 0.01 & 0.03 & -0.76 & -0.07 & 0.07 \\
\hline NN & -2.54 & -0.02 & 0.00 & -2.88 & -0.06 & 0.00 & -6.08 & -0.23 & -0.06 \\
\hline Pekao & -4.87 & -0.04 & -0.01 & -6.38 & -0.13 & -0.02 & -14.30 & -0.47 & -0.05 \\
\hline PZU & -4.45 & -0.04 & -0.01 & -3.50 & -0.07 & 0.10 & -6.23 & -0.20 & 0.09 \\
\hline MetLife & -5.03 & -0.05 & -0.01 & -4.50 & -0.08 & 0.00 & -19.14 & -0.55 & 0.08 \\
\hline Paribas & -1.64 & -0.02 & 0.00 & -0.06 & 0.00 & 0.02 & 2.74 & 0.07 & 0.07 \\
\hline CA & 1.18 & 0.01 & 0.01 & 4.13 & 0.08 & 0.04 & 11.40 & 0.41 & 0.22 \\
\hline Mill & -5.81 & -0.05 & -0.01 & -6.41 & -0.12 & -0.02 & -23.22 & -0.74 & -0.17 \\
\hline
\end{tabular}

Analysis of last two periods lets us conclude that in period $\mathrm{f}$ (Table 17) only three funds obtained a positive risk premium for all three frequencies of measurement: FIO Aviva, Credit Agricole and PZU, although only the first two can be classified as efficient funds. In period $\mathrm{g}$ (Table 18) there are only negative risk premiums; however, there are only three funds which are ineffective: Allianz, Pekao and MetLife, since Millennium shows a Sharp ratio value evaluated for weekly returns bigger than the one calculated for WIG.

Table 17. Average values of Sharpe, Treynor and Jensen efficiency ratios evaluated for mutual funds for period f (source: own calculations)

\begin{tabular}{|l|c|c|c|c|c|c|c|c|c|}
\hline \multirow{3}{*}{ Measure } & \multicolumn{9}{|c|}{ Returns } \\
\cline { 2 - 11 } & \multicolumn{3}{|c|}{ daily } & \multicolumn{3}{c|}{ weekly } & \multicolumn{3}{c|}{ Monthly } \\
\cline { 2 - 11 } & $(6)$ & $(7)$ & $(8)$ & $(6)$ & $(7)$ & $(8)$ & $(6)$ & $(7)$ & $(8)$ \\
\hline Allianz & -4.80 & -0.05 & -0.02 & -8.69 & -0.19 & -0.06 & -17.66 & -0.74 & -0.34 \\
\hline AVIVA & 1.88 & 0.02 & 0.00 & 2.91 & 0.06 & 0.01 & 16.34 & 0.80 & 0.11 \\
\hline PKO & -1.04 & -0.01 & 0.00 & -3.73 & -0.08 & -0.01 & -0.62 & 0.19 & 0.01 \\
\hline NN & -0.33 & 0.00 & 0.00 & -1.78 & -0.04 & -0.02 & 2.52 & 0.11 & -0.09 \\
\hline Pekao & -2.20 & -0.02 & -0.01 & -4.57 & -0.09 & -0.05 & -2.55 & -0.10 & -0.25 \\
\hline PZU & 0.90 & 0.01 & 0.00 & 2.04 & 0.04 & 0.00 & 12.86 & 0.48 & 0.00 \\
\hline MetLife & -1.22 & -0.01 & -0.01 & -4.09 & -0.08 & -0.04 & -0.14 & 0.01 & -0.05 \\
\hline Paribas & -1.91 & -0.02 & -0.01 & -5.23 & -0.11 & -0.04 & -6.15 & -0.28 & -0.15 \\
\hline CA & 1.95 & 0.02 & 0.00 & 2.70 & 0.07 & 0.01 & 14.30 & 0.79 & 0.08 \\
\hline Mill & -1.70 & -0.02 & -0.01 & -1.73 & -0.03 & -0.03 & -0.45 & -0.01 & -0.20 \\
\hline
\end{tabular}


Table 18. Average values of Sharpe, Treynor and Jensen efficiency ratios evaluated for mutual funds for period g (source: own calculations)

\begin{tabular}{|l|c|c|c|c|c|c|c|c|c|}
\hline \multirow{3}{*}{ Measure } & \multicolumn{9}{|c|}{ Returns } \\
\cline { 2 - 11 } & \multicolumn{3}{|c|}{ daily } & \multicolumn{3}{c|}{ weekly } & \multicolumn{3}{c|}{ monthly } \\
\cline { 2 - 11 } & $(6)$ & $(7)$ & $(8)$ & $(6)$ & $(7)$ & $(8)$ & $(6)$ & $(7)$ & $(8)$ \\
\hline Allianz & -7.45 & -0.07 & -0.01 & -10.55 & -0.22 & -0.04 & -37.79 & -1.27 & -0.22 \\
\hline AVIVA & -3.41 & -0.03 & 0.00 & -4.59 & -0.09 & 0.00 & -16.87 & -0.62 & 0.01 \\
\hline PKO & -2.66 & -0.03 & 0.00 & -1.43 & -0.02 & 0.03 & -9.29 & -0.37 & 0.07 \\
\hline NN & -4.18 & -0.04 & 0.00 & -6.47 & -0.13 & 0.00 & -20.11 & -0.70 & -0.02 \\
\hline Pekao & -5.74 & -0.05 & -0.01 & -9.37 & -0.18 & -0.02 & -23.79 & -0.79 & -0.05 \\
\hline PZU & -4.73 & -0.04 & 0.00 & -4.79 & -0.09 & 0.02 & -9.83 & -0.32 & 0.23 \\
\hline MetLife & -6.44 & -0.06 & -0.01 & -7.50 & -0.14 & -0.01 & -30.29 & -0.92 & 0.02 \\
\hline Paribas & -2.90 & -0.03 & 0.00 & -3.49 & -0.07 & 0.02 & -7.43 & -0.27 & 0.12 \\
\hline CA & 0.90 & 0.01 & 0.01 & 1.30 & 0.02 & 0.04 & 5.01 & 0.18 & 0.24 \\
\hline Mill & -5.35 & -0.05 & 0.00 & -6.61 & -0.13 & 0.00 & -24.62 & -0.88 & -0.08 \\
\hline
\end{tabular}

The comparison presented in Table 19 shows that if investment efficiency is measured by Sharpe or Treynor ratios, pension funds are characterized by better performance than stable growth mutual funds managed by the same financial company, since in $73.8 \%$ of cases these ratios are bigger for the pension funds. A similar number of cases giving priority to both types of funds is observed for PZU, Aviva and PKO. Also, Jensen alpha was positive more often for pension than for mutual funds (Kompa \& Witkowska, 2016).

Table 19. Differences in efficiency ratios evaluated for FIO and OFE (source: own calculations on the basis of Tables 13-18 and Witkowska (2016, pp. 119-138)

\begin{tabular}{|c|c|c|c|c|c|c|c|c|c|c|c|c|c|c|c|c|c|c|c|c|c|}
\hline \multirow{3}{*}{ Returns } & \multicolumn{21}{|c|}{ Periods } \\
\hline & a & $\mathrm{b}$ & c & d & $\mathrm{e}$ & $\mathrm{f}$ & $g$ & $\mathrm{a}$ & b & c & d & $\mathrm{e}$ & $\mathrm{f}$ & g & $\mathrm{a}$ & $\mathrm{b}$ & c & $\mathrm{d}$ & $\mathrm{e}$ & $\mathrm{f}$ & $\mathrm{g}$ \\
\hline & \multicolumn{7}{|c|}{ daily } & \multicolumn{7}{|c|}{ weekly } & \multicolumn{7}{|c|}{ monthly } \\
\hline \multicolumn{22}{|c|}{ Sharpe ratio } \\
\hline Allianz & - & - & - & - & - & - & - & - & - & - & - & - & - & - & - & - & - & - & - & - & - \\
\hline AVIVA & + & - & - & - & - & + & - & + & - & + & + & - & + & - & + & - & - & - & + & + & + \\
\hline $\mathrm{NN}$ & - & - & - & - & + & - & - & - & - & + & - & + & - & - & - & - & - & - & + & - & + \\
\hline Pekao & - & - & - & - & - & - & - & - & - & - & - & - & - & - & - & - & - & - & + & - & - \\
\hline $\mathrm{PKO}$ & - & - & - & - & + & - & + & - & - & + & - & + & - & + & - & - & - & - & + & - & + \\
\hline PZU & - & - & - & - & - & - & - & - & - & + & + & + & - & + & + & - & + & + & + & + & + \\
\hline \multicolumn{22}{|c|}{ Treynor ratio } \\
\hline Allianz & - & - & - & - & - & - & - & - & - & - & - & _ & - & - & - & - & - & - & - & - & - \\
\hline AVIVA & + & - & - & - & - & - & + & + & - & + & + & - & + & - & + & - & - & - & - & + & - \\
\hline $\mathrm{NN}$ & - & - & - & - & + & - & + & - & - & + & - & + & - & - & - & - & - & - & + & - & - \\
\hline Pekao & - & - & - & - & + & - & - & - & - & - & - & - & - & - & - & - & - & - & + & - & - \\
\hline $\mathrm{PKO}$ & - & - & + & - & + & - & + & - & - & + & - & + & - & + & - & - & - & + & + & - & + \\
\hline PZU & - & - & - & - & - & - & + & - & - & + & + & + & - & + & + & - & - & - & + & + & + \\
\hline
\end{tabular}

Note: + and - denote the ratio evaluated for FIO is bigger or smaller than the one calculated for OFE, respectively. 


\section{Conclusions}

Modifying the rules of private pension funds in Poland caused a drop in the significance of these institutions and the capital pillar of the retirement system in Poland. The main argument given by the officials was the lack of the investment efficiency of the pension funds. Therefore, the question arose if pension fund performance was really worse than the performance of mutual funds which provided a similar investment policy as OFEs. Thus, the aims of the research were to find out which funds (pension or mutual, both managed by the same investment companies) perform better for their clients, and if changes concerning pension funds in Poland also affect the efficiency of the mutual funds which provide a stable growth investment policy.

Presented results prove that the changes introduced by the Polish government in the years 2011-2014 were not guided by the real economic justification and influenced not only the pension funds but also the whole financial market, since OFEs were very important investors on the Warsaw Stock Exchange. It is found out that the efficiency of pension funds and the capital market represented by WIG decreased after each government modification, since the risk of pension fund portfolios usually increased.

Mutual funds were usually not effective, although their efficiency seemed to increase, especially in the last considered period. Jensen alphas were positive or Sharpe and Treynor ratios were bigger for FIOs than for WIG in $47.8 \%$ of cases in period g (i.e. after the abolition of the obligatory membership in OFE), but also in periods $d$ (i.e. after the decrease of pension contribution transferred do OFE) $-43.3 \%$ and e (i.e. before the transfer of $51.5 \%$ of OFEs' assets to FUS) $-42.2 \%$. Meanwhile, the worst performance was observed in whole period of analysis $-23.3 \%$, and in periods $b$ (i.e. before the decrease of pension contribution transferred do OFE) - 18.9\%, and f (i.e. after the transfer of 51.5\% of OFEs' assets to FUS) $21.1 \%$. A comparison of the pension and stable growth investment funds' performance shows that before the drastic change had an effect at the beginning of 2014, the former constructed less risky portfolios than FIOs. It was also proved that, regardless of the frequency of data, pension funds were more effective than stable growth mutual funds, especially in periods a, $\mathrm{b}, \mathrm{d}$ and $\mathrm{f}$.

In addition, presented study shows that the methodology applied in this research could be useful for assessing the impact of political, economic and legal environment on the financial market and we recommend its application. However, there are also some limitations of this methodology since time series should contain great number of observations and application of statistical inference requires meeting specific assumptions. One should also realize that presented research were conducted for selected mutual funds, operating in Poland in considered time span. Therefore, further investigation should consider funds providing different investment strategies.

\section{References}

Akpinar, O. (2014). Performance evaluation of pension funds and mutual funds in Turkey and the timing ability of fund managers. British Journal of Economics, Finance and Management Sciences, 9(1). 
Blake, D., Wright, D., \& Zhang, Y. (2014). Age-dependent investing: Optimal funding and investment strategies in defined contribution pension plans when members are rational life cycle financial planners. Journal of Economic Dynamics and Control, 38, 105-124. https://doi.org/10.1016/j.jedc.2013.11.001

Boon, L. N., Brière, M. \& Rigot, S. (2018). Regulation and pension fund risk-takin. Journal of International Money and Finance, 84(C), 23-41. https://doi.org/10.1016/j.jimonfin.2018.01.005

Brinkman, J., Coen-Pirani, D., \& Sieg, H. (2018). The political economy of municipal pension funding. American Economic Journal: Macroeconomics, 10(3), 215-246. https://doi.org/10.1257/mac.20160400

Chybalski, F. (2006). Miary oceny działalności inwestycyjnej OFE [Measures of pension fund investment efficiency]. Wiadomości Statystyczne. The Polish Statistician, 10, 22-35 (in Polish).

Dybał, M. (2017). Private pension - benefit expenditures. Economic and Environmental Studies, 17(1), 127-137.

Dziennik Ustaw. (2014). Official Gazette of the Republic of Poland, poz. 753.

Jame, R. (2010). Organizational structure and fund performance: pension funds vs. mutual funds. Retrieved from https://ssrn.com/abstract=1540533 https://doi.org/10.2139/ssrn.1540533

Jensen, M. C. (1968). The performance of Mutual Funds in the period 1945-1964. Journal of Finance, 23(2), 389-416. https://doi.org/10.2307/2325404

Jensen, M. C. (1969). Risk, the pricing of capital assets, and the evaluation of investment portfolios. Journal of Business, 42(2), 167-247. https://doi.org/10.1086/295182

Karpio, A., \& Żebrowska- Suchodolska, D. (2016). Polish open-end pension funds' performance and its persistency. Acta Scientiarum Polonorum, Oeconomia, 15(1), 15-25.

Kurach, R. (2017). International diversification of pension funds using the cointegration approach: The case of Poland. Transformations in Business \& Economics, 16(2(41)), 42-54.

Kompa, K. (2018). Efficiency of mutual funds in Poland in the years 2009-2015. Łódź: University of Lodz (forthcoming).

Kompa, K., \& Wiśniewski, T. (2015). Dywersyfikacja portfeli otwartych funduszy emerytalnych kaprys czy konieczność? [Diversification of open pension funds' portfolios - whim or necessity?]. Finanse, rynki finansowe, ubezpieczenia Zeszyty Naukowe Uniwersytetu Szczecińskiego, 862, 245-255 (in Polish). https://doi.org/10.18276/frfu.2015.75-20

Kompa, K., \& Witkowska, D. (2015a). Pension system in Poland: Performance of pension funds. Estudios De Economia Aplicada, 33(3), 965-984.

Kompa, K., \& Witkowska, D. (2015b). Transformation of Polish pension system: Government manipulations instead of improvement. In J. M. Montero Lorenzo, J. M. Jiménez, \& R. M. Salido (Eds.), Sostenibilidad y Suficiencia de los Sistemas de Pensiones [Sustainability and Sufficiency of Pensions Systems] (XXIX, pp. 836-846). Anales de Economía Aplicada.

Kompa, K., \& Witkowska, D. (2016). Performance of pension funds and stable growth open investment funds during the changes in the Polish retirement System. Dynamic Econometric Models, 16, 117131. https://doi.org/10.12775/dem.2016.007

Mentel, G., Brozyna, J., \& Szetela, B. (2017). Evaluation of the effectiveness of investment fund deposits in Poland in a time of crisis. Journal of International Studies, 10(2), 46-60. https://doi.org/10.14254/2071-8330.2017/10-2/3

Mentel, G., Brożyna, J., Szetela, B., \& Kompa, K. (2016). Macro and microeconomic factors of investment efficiency of open investment funds in the period of 1997-2015. Transformations in Business \& Economics, 15(3(39)), 122-140.

Mentel, G., \& Horvathova, Z. (2016). Factors of efficiency of open investment funds in 1997-2015. Economics and Sociology, 9(1), 101-113. https://doi.org/10.14254/2071-789x.2016/9-1/7 
National Bank of Poland. (2018). Financial system in Poland 2017. Warsaw: National Bank of Poland.

Ngugi, W., \& Njuguna, A. (2018). Nexus between pension fund size, design and investment strategy: a review of occupational retirement benefits schemes in Kenya. International Journal of Financial Research, 9(3), 108-116. https://doi.org/10.5430/ijfr.v9n3p108

Ostrowska, E. (2003). Efektywność funduszy inwestycyjnych na polskim rynku finansowym - wskaźniki Sharpe'a, Treynora i Jensena [Efficiency of mutual funds on Polish financial market - Sharpe, Treynor and Jensen ratios]. In K. Jajuga \& W. Ronka-Chmielowiec (Eds.), Prace naukowe akademii Ekonomicznej we Wrocławiu, Inwestycje finansowe i ubezpieczenia - tendencje światowe a polski rynek. Wrocław: Wydawnictwo Akademii Ekonomicznej we Wrocławiu (in Polish). https://doi.org/10.15611/pn.2016.449.26

Otto, W., \& Wiśniewski, M. (2013). Stopy zwrotu: OFE i ZUS [Rates of return from open pension funds (OFE) and Social Insurance Institution (ZUS)]. Retrieved from http://kobe.org.pl/wp-content/uploads/2013/06/Stopy-Zwrotu-w-OFE-a-indeksacja-sk\%C5\%82adek-w-ZUS.pdf

Sharpe, W. F. (1966). Mutual fund performance. Journal of Business, 39(1), 119-138. https://doi.org/10.1086/294846

Treynor, J. L. (1965). How to rate management of investment funds. Harvard Business Review, 43(1), 63-75.

Tripathy, N. (2017). Efficiency of mutual funds and performance measurement in India: An empirical investigation. International Journal of Business Excellence, 13(2), 217-237. https://doi.org/10.1504/ijbex.2017.086338

Witkowska, D. (2009). Efektywność wybranych funduszy akcyjnych w latach 2005-2007 [Efficiency of selected mutual equity funds in the years 2005-2007]. Ekonomika i Organizacja Gospodarki Żywnościowej, 74, 39-61.

Witkowska, D. (2016). Zmiana warunków funkcjonowania a efektywność inwestycyjna otwartych funduszy emerytalnych [The change of functioning conditions vs investment efficiency of open pension funds]. Łódź: University of Lodz (in Polish).

Witkowska, D., \& Kompa, K. (2017). Polish pension market performance in comparison to selected benchmarks, Economics \& Sociology, 10(1), 35-47. https://doi.org/10.14254/2071-789x.2017/10-1/3

Zamojska, A. (2012). Efektywność funduszy inwestycyjnych w Polsce. Studium teoretyczno-empiryczne [The efficiency of mutual funds in Poland. A theoretical and empirical study]. Warszawa: C. H. Beck (in Polish). 